\title{
Here Comes A2 Milk to the Rescue, A Review
}

\author{
George FW Haenlein* \\ Professor emeritus, Animal \& Food Sciences, University of Delaware, USA
}

Submission: November 3, 2017; Published: November 17, 2017

*Corresponding author: George F. W. Haenlein, professor emeritus, Animal \& Food Sciences, University of Delaware, USA,

Email: ghaenlein@gmail.com

\begin{abstract}
By definition of the US Board of Health, milk is an unadulterated product from a healthy cow's udder and for reasons of healthy nutrition the consumption of 3 glasses of milk per day are recommended for adult persons. None of which is however achieved according to many surveys, because many consumers experience digestive upsets, bloat and other stomach pains. One reason is the inability of many consumers to digest the sugar in milk, called lactose and the term lactose intolerance was coined. Another reason is that in some consumers the cow milk produces allergic reactions. Thus the call for alternative milks has been raised. The US Board of Health definition of milk now had to include alternative kinds or sources of milk. Naturally goat milk, which is so widely available on a non-commercial basis mostly, was a logical choice, and which proved also successful. This then called for research to identify reasons why alternative milks such as goat milk are tolerated by allergy afflicted people, and the testing of milk for genetic variations was started. Soon the different proteins, alpha, beta, kappa, lacto globulin, etc. were identified and many genetic mutations were recognized. The logical next step has been to translate this new knowledge into the practice of milk production from cows or goats or even whole herds. And this actually is happening with the advent of so-called A2 cow milk or alpha-s- 2 goat milk to the rescue of people with afflictions when drinking traditional milk or allergic reactions.
\end{abstract}

Keywords: Dairy Goats; Cow Milk Allergy; Alpha-S-2 Casein Milk; A2 Beta Casein Milk

\section{Introduction}

It used to be that according to the standard definition by the Board of Health in each US state milk was defined as being an unadulterated product from cows' udders. Then came the realization that the consumption of fluid milk was not as much as it was recommended by health and nutrition authorities, like 3 glasses per adult person per day. Thus milk as it came from the cow had to be made more consumers friendly and $2 \%$ milk, i.e. with only $2 \%$ fat, was brought into the market place, changing the purity definition of unadulterated milk for the first time. Thereafter skim milk, i.e. with no fat content, was also entered into the market place. Again the level of consumption of milk of the 3 glasses per day was not achieved. It was realized that there were still many people who either did not want or could not drink milk for reasons of one of two major health problems.

\section{Lactose Intolerance}

One was the occurrence of digestive upsets, bloats and stomach pains after drinking any of the now 3 types of milk available. The diagnosis was an inability of adult persons to digest the sugar in milk called lactose and the term lactose intolerance was coined, which was due to the absence of a digestive enzyme in the human adult intestinal tract called lactase. The solution in the market place was to offer either lactose-free milk or lactase supplemented milk, called Lactaid. Thus the unadulterated purity definition of cow milk now had 4 exceptions in the market place: $2 \%$, skim, and lactose-free, lactate-supplemented milk. Still consumption of 3 glasses of some kind of milk was lagging.

\section{Other Milk Option}

To boost milk consumption there was the option of either adding chocolate, fruit flavors or other flavor substances or to changing the source of milk from cow to some other milk producing domestic animal, as was already practiced in parts of the world outside of the USA, such as goat milk, sheep milk, buffalo milk, camel milk, yak milk and reindeer milk, which all are consumed by some people in regions of the world where cows are not popular or practical for reasons of climate or geography. Thus the purity definition of cow milk had to be changed again by US Departments of Health to include that milk could also be produced by dairy goats besides dairy cows, and soon dairy sheep had also to be added and we now even have in the USA some dairy buffalo herds and dairy camel 
farms producing their different milk. What these other milks are addressing in the market place is that some milk drinkers still have one other major health problem, i.e. cow milk allergy. Encouraged by several research trials, when cow milk allergic people were changed from cow milk to goat milk drinking, their allergy symptoms of skin rash, ekzema and other dermatitis problems disappeared in 2 out of 3 people. Thus non-allergenic milkman be made available in the market place.

\section{Different Milk Proteins}

Research has shown that it is certain proteins in milk that can cause allergic reactions when consumed by humans. Also it is known that milk contains more than one kind of protein, all or any of which can be allergenic. The major proteins in milk, composed of chains of amino acids hooked together, are the cheese yielding three kinds called Casein, specifically alpha, or alpha-s, beta and kappa casein. Each has some variation in their amino acid composition which is identified by chemists with letters and numbers such A1, A2, A3, B, D, E, F, etc. identifying more specifically which type alpha-s or beta or kappa casein is present in a particular cow's or goat's milk and each may be more dominant in the milk of one cow or goat than in another. This explains why goat milk casein is different from cow milk casein because of differences in their amino acid composition. In fact most dairy cow milk casein contains the alpha-s- 1 casein and little alpha-s-2 casein. Goat milk in comparison often has just the opposite composition, namely mostly alpha-s-2 and little or no alpha-s-1. Cheeses making dairy farmers have a preference for alpha-s- 1 milk because it produces more cheese from a harder curd in contrast to alpha-s-2 milk which produces a softer curd at a lower yield but with an easier digestibility in human nutrition.

\section{Goat Milk}

Recent research in Italy has found that these two basic differences of amino acid composition between alpha-s- 1 and alpha-s-2 casein may be responsible for the allergen city of cow milk with alpha-s-1 casein in contrast to the non-allergen city of goat milk with alpha-s-2 casein [1]. US dairy goat owners now can have their dairy goats tested for a small fee for the existence or absence of alpha-s-1 casein in the milk of their goats at the Veterinary Genetics Laboratory of the University of California at Davis under contract with the American Dairy Goat Association [2]. The reason for this testing opportunity is that alpha-s-1 casein has a significantly higher cheese yield than alpha-s- 2 casein milk. Unfortunately the value of alpha-s-2 casein for its potential non-allergen city is ignored and that this can justify the alternative use of this kind of goat milk for people with that affliction.

\section{Milk Protein Testing}

On the other hand dairy cow people have recognized the practical aspects of recent research of the characteristics of beta and kappa casein and beta-lacto globulin variants and their correlation with higher cheese yields from some compared to others [3]. The testing for beta casein claims that health benefits are associated with the consumption of $\mathrm{A} 2$ beta casein milk compared with A1 beta casein. Testing for kappa casein, A, B or E variants, is also supposed to produce $8 \%$ higher cheddar cheese or $12 \%$ higher mozzarella cheese yield from BB milk compared to AA or AE milk. Even testing for beta lacto globulin protein BB is supposed to identify significantly more cheese yield than from milk of the A variant.

\section{Alpha-S-2 Casein Milk}

What is new is that this testing is translated into animal breeding selection practice by farmers creating entire herds of cows or goats with the genetic ability of producing only one or the other type casein in their milk. This new technological testing of the Neogen program is provided widely by the service of the Merck Animal Health Company. However it does not include testing for alpha-s casein, which the ADGA program does [2].Thus potentially non-allergenic milk from alpha-s-2 casein milk could be created from entire herds of goats and that is a challenge to dairy goat owners to establish herds of goats having only alpha-s- 2 casein in their milk and to have a new advantage in the market place to be of help to allergy sufferers [4].

\section{A2 Beta Casein Milk}

The amazing fact is that actually a herd of dairy cows now exists in California consisting only of cows with the A2 beta casein producing ability trying to take advantage in the market place to help people with health concerns to be able to drink more of their recommended 3 glasses of milk per day $[5,6]$. Thus there is now new milk, the $\mathrm{A} 2$ beta casein, and does it come to the rescue of consumers?

\section{References}

1. Bevilacqua C, Martin P, Candalh C, Fauquant J, Piot M, et al. (2000) Allergic sensitization to milk proteins in guinea pigs fed cow milk and goat milks. In: Proceedings $7^{\text {th }}$ International Conference on Goats. In: L Gruner \& Y Chabert (Eds.), Institute d'Elevage Publ, Tours, France, Vol II, pp 874-879.

2. ADGA (2016) Annual Program American Dairy Goat Association, Spindale, NC 28160, p 24.

3. Neogen Corporation (2015) Igenity Dairy Heifer Program. Distributed by Merck Animal Health Co. Neogen: GeneSeek Operations Publ, 4131 N 48 ${ }^{\text {th }}$ Street, Lincoln- NE 68504, USA, pp 10.

4. Ellie Krieger (2017) Personal communication.

5. Park YW, Haenlein GFW, Wendorff WL (2017) Handbook of Milk of Non-Bovine Mammals. Wiley-Blackwell Publishers, Oxford- U.K, $\left(2^{\text {nd }}\right.$ edn), pp 700.

6. California Research Foundation (2017). 
This work is licensed under Creative Commons Attribution 4.0 License DOI: $10.19080 /$ NFSIJ.2017.03.555625

\section{Your next submission with Juniper Publishers} will reach you the below assets

- Quality Editorial service

- Swift Peer Review

- Reprints availability

- E-prints Service

- Manuscript Podcast for convenient understanding

- Global attainment for your research

- Manuscript accessibility in different formats ( Pdf, E-pub, Full Text, Audio)

- Unceasing customer service

Track the below URL for one-step submission https://juniperpublishers.com/online-submission.php 